\title{
Effect of UMMB Supplementation during Winter on the Milk Production and Its Composition and Infertility in Dairy Cattle in Hill Management Production System
}

\author{
Chet Raj Upreti ${ }^{1}$, Bashanta Kumar Shrestha ${ }^{2}$ and Binaya Ghimire ${ }^{3}$ \\ ${ }^{1}$ Bovine Research Program, Khumaltar, ${ }^{2}$ Animal Nutrition Division, NARC, Khumaltar \\ ${ }^{3}$ Vet for your Pet, Bhaktapur \\ e-mail:crupreti55@gmail.com
}

\begin{abstract}
Two groups, each containing 10 lactating cross bred Jersey cows were used to evaluate their feeding response on their milk production level and its quality in the mid hill's livestock production and management system. Ten infertile Jersey cows were also selected for infertility study. The objective of the study was to evaluate on the response of Urea Molasses Mineral Block (UMMB) feed supplements in two management systems on the milk production, composition, and correction in infertility problem. Two sites of different management system, namely Saaradabatase and Naala in Kavrepalanchok district, were used to conduct the research for two years. Research was conducted during winter from February to April 2007 and 2008 for 60 with 7 days adjustment period in each site. Ten lactating dairy cows were supplemented with UMMB and ten without UMMB for 30 days. In each location, both groups were recorded for their milk yield and milk quality (milk fat and SNF \%). After 30 days, group A was stopped to offer block group and B was started to supplement UMMB for 30 days. Two kg blocks were fed in UMMB feeder (wooden made) to control the intake. In Ugrachandi Nala site i.e site A 25\% green grass was offered. But in Saaradabatase , site B, rice straw was used as basal diet with or without small amount of green grass as per availability. Among the total 8 repeatedly breeding Jersey cattle, 25\% i.e. 2 animals, came into heat and conceived due to the positive effect of UMMB. Body condition score was improved from 3.5 to 4 due to the effect of UMMB supplementation. A simple economical calculation was done to find out the net income. A net daily profit of NRs 10.77 per animal in Saaradabatase and NRs 5.96 in Nala was recorded with the UMMB fed group compared to control group. Study has concluded that UMMB as a feed supplement in the mid hill management is economical for winter feeding. UMMB supplementation is one of the means to correct infertility problem and for better condition score in dairy cattle.
\end{abstract}

Key words: infertility, management system, milk production, rice straw, UMMB

\section{Introduction}

Cattle and buffalo have significant contribution on national milk production. But these ruminants demand more feed due to their longer body size. During dry winter season, animal feed is in shortage by 36 percent in Nepal (Pande 1997). Crop residue mainly rice straw, corn stover, wheat straw, millet straw, and other similar types of residues are used to feed these ruminant. These feed resources are very poor in nutrient contents which are even not able to supply the nutrients required for maintaining the animals. However, these feedstuffs can be improved in quality and utilized by supplementing with certain feed supplements such as urea molasses mineral block (UMMB). UMMB blocks can be prepared in desired size (generally of $2 \mathrm{~kg}$ in brick size) and offered for licking by the animals which provide them energy and protein for the rumen microbes. It has become important to mechanize its production, improve the formula, and increase the 
production to cover wide areas of distribution to benefit many dairy farmers in the country (Avilla 2006).

UMMB contains urea, molasses, rice bran, and binding agents. Different ingredients used in UMMB have major roles in ruminant feeding such as (1) Urea: provides small amount of extra nitrogen required for utilization of the dry matter. Nitrogen must be sufficient to maintain the ammonia level in the rumen, at a constant and sufficient amount for better development of the rumen microbes leading to better degradation of the cellulosic components. (2) Molasses: a good source of energy, being a concentrated plant juice, provides a range of minerals (except phosphorus) and a complete mixture of vitamins. It should have more than $80^{\circ}$ Brix. (3) Minerals: they correct the macro and trace minerals deficiency in animal diet (4) Cement or quick limes: it is used as binding agent.

The use of UMMB feed as supplement is to improve on the nutrient contents and straw utilization. The blocks are easy to handle, transport, and commercially feasible to manufacture (Avilla 2006).

Feeding of UMMB to cattle usually results in increasing in feed intake by 25 - 30\% and its digestibility (Aarts et al. 1990, Upreti 2008). UMMB supplementation in animal feed increases microbial protein in the animal body which saves the expensive concentrates. It has also been documented that feeding UMMB increases or maintains body condition, and production of ruminant animals during winter on straw based diet.

The objective of the research was to study on the effect of UMMB supplementation to cow's diet in straw on the milk production, milk quality, body condition score, and infertility in farmer's management system.

\section{Methodology Housing of experimental animals}

Two V.D.C. of Kavrepalaanchok district, namely (1) Saaradabatase and (2) Ugrachandi, Nala were selected to conduct the experiment. These two sites were different with agricultural system, and feeding management of cattles. Saaradabatashe was dry and animals were fed only crop residue but Nala had green grasses available to the lactating dairy animals. Animals in these two sites were stall-feed and camped inside during night. Feeding system was cut and carries in Nala while there was no green grass to cut and feed to the animal in Saaradabatase. Animals were conventionally managed in both sites.

\section{Animals and experimental design}

Twenty lactating crossbred dairy cattle in each site were selected for the experiment. Feeding was done three times in 24 hours. Out of the 20 cattle, ten lactating animals were supplemented with UMMB and 10 were without it for 30 days. Both groups were recorded for milk yield and its composition. After 30 days, group A was stopped to provide block and group B was provided UMMB for 30 days. Two kilogram blocks were fed in UMMB feeder (wooden box) to control the intake. During milking, twice (morning and evening) a day, the blocks were offered to lick by the animals. Fresh drinking water was made available to the animals throught-out the experimental period. Green grass (25 $\%$ of diet) was offered at Nala site but at Saaradabatase all feed was straw based with or without small amount of green grass as per availability. Rice straw was offered ad libitum.

\section{Dietary treatments}

\begin{tabular}{|c|c|}
\hline Site & Dietary treatments \\
\hline Saaradabatase & $\begin{array}{l}\text { Group A : With UMMB for } 10 \text { animal for } 30 \text { days and the same } \\
\text { animals without UMMB for } 30 \text { day. } \\
\text { Group B : Without UMMB for } 10 \text { animals for } 30 \text { day, and same } \\
\text { animals with UMMB for } 30 \text { days. }\end{array}$ \\
\hline Nala & $\begin{array}{l}\text { Group A : With UMMB for } 10 \text { animals for } 30 \text { day, and same } \\
\text { animals without UMMB for } 30 \text { day. } \\
\text { Group B : Without UMMB for } 10 \text { animal for } 30 \text { day, and same } \\
\text { animals with UMMB for } 30 \text { days. }\end{array}$ \\
\hline
\end{tabular}




\section{UMMB preparation and block composition}

The preparation of UMMB has of four stages:

1. Preparation of feed ingredients; as per the formula presented below.

2. Mixing the feed ingredients: Small amounts were mixed first and added to the bulk and then thoroughly mixed.

3. Molding: Mixed materials were packed in metal container (capacity of $2 \mathrm{~kg}$ ) and pressed with blocker for 3 minutes.

4. Drying: Blocks were dried under shed for 7 days.

\section{UMMB block dimension}

Formula developed and tested by Nepal Agricultural Research Council (NARC) was used to formulate the UMMB. A blocker was used which was developed by Animal Nutrition Division, NARC as described in results and discussion.

A technical specification of a block is as follows. (1) Bulk density $=1.55 \mathrm{~kg} / \mathrm{cm}^{3}$ (2) Weight $=2000 \mathrm{~g}$, (3) Length $=19 \mathrm{~cm}$, (4) Breadth $=12 \mathrm{~cm}$, (5) Height $=5.6$ $\mathrm{cm}$, (6) Compression $=3.54 \%$, (7) Setting time $=3 \mathrm{~min}$.

\section{Block composition}

Following ingredients were used to prepare the UMMB: (1) urea (10\%), (2) molasses ( $>80^{\circ}$ brix) (32\%), (3) rice bran (36\%), (4) minerals (6\%), (5) common salt (5\%), (6) cement (6\%) (Water: cement is 2:5 as suggested by Bheekhee, 2010). , (7) dicalcium phosphate (5\%).

The keeping quality of blocks was tested and they were found safe up to 9 months if stored in cold and dry place.

\section{Analytical procedure of feedstuff}

Samples of UMMB were oven dried at $100^{\circ} \mathrm{C}$ for $24 \mathrm{~h}$. The samples were ground to pass through $1 \mathrm{~mm}$ sieve. Dry matter was determined by drying samples at $100^{\circ} \mathrm{C}$ for $2 \mathrm{~h}$, ash by heating at $600^{\circ} \mathrm{C}$ for $2 \mathrm{~h}$, protein by micro kjeldal procedure $(\mathrm{N} \times 6.25)$ following the procedure of AOAC (1999).

\section{Training to the farmers}

A one - day training was organized to the participating dairy farmers (20 in each site) to teach them technique of using UMMB in straw based feeding management system.

\section{Milk yield}

Milk yield was recorded daily both in the morning and evening.

\section{Breeding performance}

Blocks were offered to 5 crossbred repeat breeders dairy animals (out of the experimental animals) in each site to assess the repeat breeding problem of dairy cattle. The blocks were offered for 28 days.

\section{Body condition score}

Body condition scores of the experimental animals were recorded using a 1 to 5 rating scale. Scale 1 was for the best and 5 for the poorest (i.e. lean and thin).

\section{Data analysis}

All the data of the two sites were pooled while calculating the economic aspects of UMMB supplementation. Then the data were subjected to summarize using Statistix software.

\section{Results and Discussion Livestock management system}

Due to the differences in feed availability and management system in Kabhrepalanchok district, two sites were selected for the study (Table 1). Cross bred dairy animals (Jersey) were allowed to graze for $3 \mathrm{~h}$ per day at Nala but they were stall-fed at Saaradabatase. The environmental condition was cooler at Nala (due to higher altitude) than Saaradabatase which indicates comfortable management at Nala.

Table 1. Management system of dairy animals at Nala and Saaradabatase

\begin{tabular}{l|l|l|l}
\hline \multicolumn{1}{c|}{ Study sites } & \multicolumn{1}{|c|}{ Feed stuff } & Management system & \multicolumn{1}{c}{ Milk marketing system } \\
\hline 1. Saaradabatase & $\begin{array}{l}\text { Rice straw, wheat straw, potato haulm, compounded } \\
\text { feed (Himalayan feed), rice bran, maize stover }\end{array}$ & $\begin{array}{l}\text { Stall fed } \\
\text { and local people. }\end{array}$ \\
2. Nala & $\begin{array}{l}\text { Rice straw, small amount of green oats, potato } \\
\text { haulm, vegetable leaves, rice bran }\end{array}$ & $\begin{array}{l}\text { Grazing 3 h daily and } \\
\text { stall fed }\end{array}$ & Milk selling to cooperatives \\
\hline
\end{tabular}


The nutrient contents of feed ingredients have been presented in Table 2. Daily nutrient requirement was met while offering the feeds. Crude protein of the UMMB was higher (32.68\%) than $23.0 \%$ reported by Avilla (2006).

\section{UMMB preparation and feeding management}

UMMB blocker was fabricated with the help of Engineering Division of Nepal Agricultural Research Council (NARC). This type of blocker was suggested by various Indian Research Institutes. But they manufactured the commercial type, whereas the present fabrication is semi-commercial type which can be produce 36 blocks of $2 \mathrm{~kg}$ per hour. The block setting time was reduced to 3 minutes from 15 minute with manual wooden blocker. The technical specification of the blocker was suitable to compress enough for better toughness of the block. Blocks were hard enough for transport. The keeping quality was good up to the nine months period. A suitable block offering technique was identified for feeding twice a day. To control over licking, the block was offered before milking and withdraw immediately after milking.
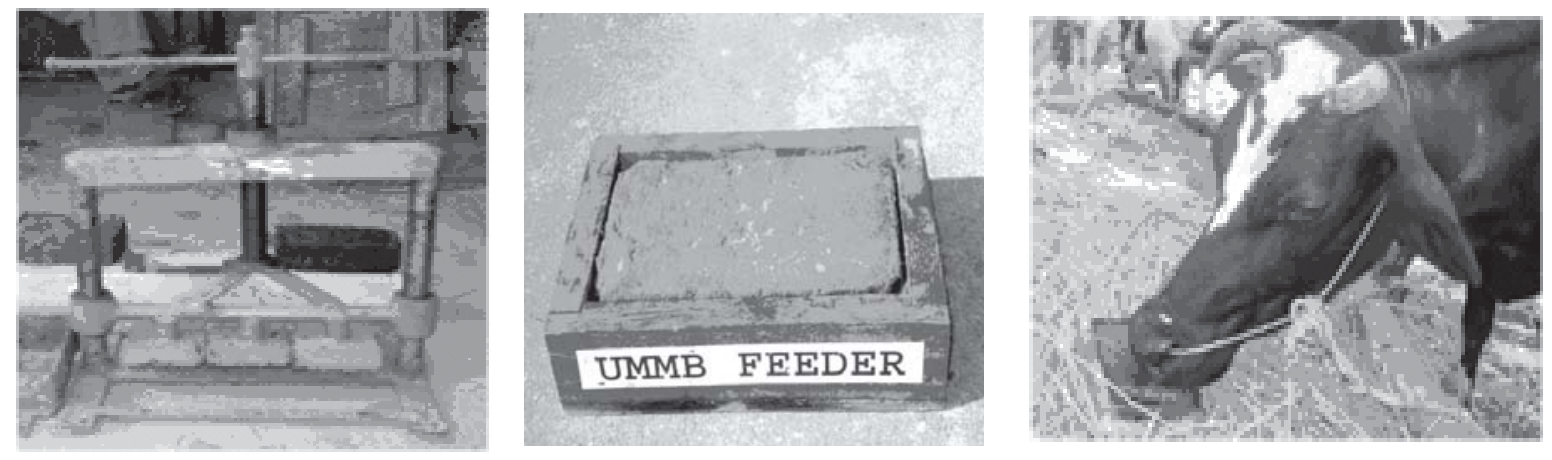

Fig. 1. Preparation and use of UMMB by lactating dairy cattle in experimental field

\section{Farmers' perception}

During the training process, farmers were asking questions about the use of cement in the block. Information was provided about the safeties of cement. The cement as feed ingredient is safe in UMMB. Studies conducted in Canada and USA on the utilization of cement and its by-products as minerals for animals did not reveal any negative effect when

Table 2. Chemical composition of ingredients fed up to a maximum of 1 to $3 \%$ of the total daily dry matter intake (Aarts et al. 1990, Makkar 2001). After termination of the experiment, farmers were asked about the impression of cement. They were fully satisfied that cement feeding at lower level was safe for their animals. No negative effect was observed in other experiments conducted over 5 years in farmers' field (Anonimous 2010).

\begin{tabular}{l|l|l|llll}
\hline Ingredient & DM(\%) & CP & E & Fiber & Ca & P \\
\hline Rice bran & 87.83 & 12.52 & 9.90 & 8.33 & 0.14 & 0.71 \\
UMMB & 85.63 & 32.38 & - & 5.42 & 5.91 & 2.0 \\
\hline
\end{tabular}

$\mathrm{DM}=$ Dry matter, $\mathrm{CP}=$ crude protein, $\mathrm{EE}=$ ether extract, $\mathrm{Ca}=$ calcium, $\mathrm{P}=$ phosphorus

\section{Milk production}

UMMB supplemented group of cows recorded higher level of milk production in both sites compared to the control groups as shown in Table 3. A higher level of milk production at Nala, although the production level was not significantly higher ( $p>0.05)$, could be due to two reasons. Firstly, due to the daily free grazing at least for $3 \mathrm{~h}$, and secondly, use of green roughage (although in small quantity). Milk production differences were higher at Nala (0.06 and $0.03 \mathrm{l} / \mathrm{d} / \mathrm{a}$ for treated and control groups respectively) although 
higher production was not significant, as shown in Table 3. Average total daily milk production per animal of two sites increased by 17.7 \% (i.e.1.1 liter per animal per day) in UMMB fed animals compared to control groups. This increased production level is lower as reported by Avilla (2006) where he reported $21 \%$ milk increment. Mandal et al. ( 2001) reported that there is positive co-relation between gradually increased UMMB intake and level of milk yield. They further reported that milk yield was $49.76 \%$ higher in UMMB supplementation than in the control group in 140 days experimental period. Indonesian work has shown that the potential of milk increment is $14 \%$ per lactation (Makkar 2001).

A comparative study on Holstein cross and Sahiwal cross bred animals has shown the milk increment of 1.87 (6.48 vs $5.61 \mathrm{l} / \mathrm{d} / \mathrm{a})$ and 1.77 (3.95 vs $4.72 \mathrm{l} / \mathrm{d} / \mathrm{a})$ liter of milk/animal/head (Khan \& Chaudhari 2000) whereas in our study average daily milk increment was 1.11 (Table 3). Recent study in Mahadev Beshi, Dhading has recorded an average $2.0 \mathrm{l}$ milk production increased $(\mathrm{P}<0.01)$ per day per animal (Anonimous 2010).

\section{Milk composition}

Contents of fat and solid not fat (SNF) were analyzed to find the change in milk composition due to the supplementary feeding of UMMB in dairy animals. SNF content was higher in UMMB supplemented group compared to the control group. Makkar (2001) reported that SNF increment was by $3 \%$ when UMMB was supplemented to lactating animals.

\section{Fat content}

Fat content in milk was used to assess the milk composition if there were any changes. Fat content, even in the control group, recorded higher by $0.43 \%$ and this may be due to the better feeding management of experimental animals and latter stage of lactation. UMMB supplemented group had higher fat increment level of $0.68 \%$ compared to the control group. This has clearly indicated that the positive effect of UMMB supplement on fat production during winter dry period with dry roughage feeding. Study in Indonesia showed that increase in fat was $11 \%$ with UMMB supplementation (Makkar 2001).

Table 3. Effect of UMMB supplementation on milk production and nutrient composition

\begin{tabular}{l|c|c|c|c|c|c}
\hline \multirow{2}{*}{ Research Sites } & \multicolumn{2}{|c|}{$\begin{array}{c}\text { Average milk production } \\
\text { (1/d/animal) }\end{array}$} & $\begin{array}{c}\text { Average milk production } \\
\text { differences(l) }\end{array}$ & $\begin{array}{c}\text { Average fat \% } \\
\text { increased (1/d/a) }\end{array}$ & $\begin{array}{c}\text { Average fat production } \\
\text { differences (\%) }\end{array}$ \\
\cline { 2 - 7 } & $\begin{array}{c}\text { Without } \\
\text { UMMB }\end{array}$ & $\begin{array}{c}\text { With } \\
\text { UMMB }\end{array}$ & & $\begin{array}{c}\text { Without } \\
\text { UMMB }\end{array}$ & $\begin{array}{c}\text { With } \\
\text { UMMB }\end{array}$ & \\
\hline 1. Saaradabatase & $6.24 \pm 0.11$ & $7.37 \pm 0.12$ & 1.13 & $0.41 \pm 0.01$ & $1.12 \pm 0.02$ & 0.71 \\
2. Nala & $6.30 \pm 0.13$ & $7.40 \pm 0.15$ & 1.1 & $0.45 \pm 0.02$ & $1.10 \pm 0.01$ & 0.65 \\
$\begin{array}{l}\text { Average milk/fat } \\
\text { production (\%) }\end{array}$ & 6.27 & 7.38 & 1.11 & 0.43 & 1.11 & 0.68
\end{tabular}
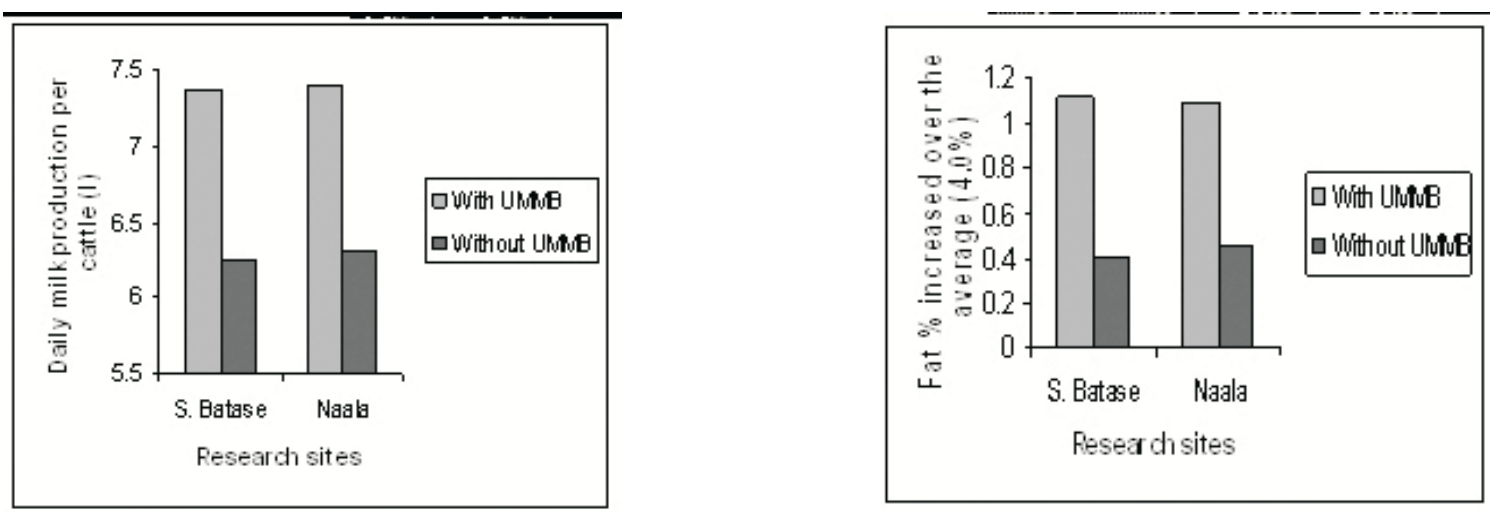

Fig. 2. Milk and butter fat increment Of UMMB fed dairy cattle. 


\section{SNF content}

Study in Indonesia showed that increase in SNF in milk was $3 \%$ (Makkar 2001). In the present study the SNF \% was increased by $5 \%$.

\section{Infertility correction}

Out of 10 repeat breeders 3 cows supplemented with UMMB came into heat (30\%) within 21 days indicating the effect of block supplementation to correct the infertility problem due to nutritional deficiency (Table 4). A similar study in Indonesia has recorded $15.8 \%$ improvement in conception rate (Makkar 2001). In his/her study, even the service per conception was reduced (2 vs 2.48). The present study does not consider some major reproductive parameters such as the effect of calving interval, age at first calving, age at first insemination and age at first estrus. For these parameters, a positive response has been recorded in other experiments (Makkar 2001).

Table 4. Infertility correction in different management system in the research sites

\begin{tabular}{l|c|c}
\hline \multirow{2}{*}{ Research sites } & \multicolumn{2}{|c}{ Infertility correction } \\
\cline { 2 - 3 } & Without UMMB & With UMMB \\
\hline 1. Saaradabatase & $0 / 5$ & $1 / 5$ \\
2. Nala & $0 / 5$ & $2 / 5$ \\
\hline
\end{tabular}

\section{Economic return from UMMB supplementary feeding}

A simple economical calculation was done. An additional net daily profit per animal of NRs 10.77 was recorded in Saaradabatase with the UMMB supplemented group. But additional daily profit recorded was lower in Nala (NRs 5.96) over the control group (without UMMB supplementation) (Fig.2).

Animal with an average 9 liters of milk can earn Rs 96.93 per animal per day in case of Saaradabatase and similar location of the nation.

\section{Body condition score}

Body condition score (rating from 1 to 5 ) of the experimental animals was improved from average 3.5 (before experiment) to 4 scores (after experiment). Achieving 4 conditional scores in dairy cattle have great importance during winter in the hills of Nepal.

The finding of this study showed that UMMB supplementation with straw based diet during winter to the dairy cattle is profitable. Both the milk production and quality can be improved with UMMB supplementation. Further, study has revealed that infertility can be corrected by $25 \%$ and condition score can also be improved from 2.5 to 3.5 scales. Therefore, it can be recommended that dairy farmers should use UMMB as feed supplements in straw based diet of livestock production and management during winter in the hills to get more money and also to improve the breeding performances.

Table 5. Cost and benefit of feeding regime supplemented with UMMB in Jersey cattle

\begin{tabular}{|c|c|c|c|c|c|c|}
\hline \multirow[t]{2}{*}{ Items } & \multicolumn{2}{|c|}{ Cost of feed (Rs) A } & \multicolumn{2}{|c|}{ Return from milk (Rs) B } & \multicolumn{2}{|c|}{$\begin{array}{c}\text { Return }(\mathrm{Rs}) \mathrm{C}=(\mathrm{B}-\mathrm{A}) \\
\text { per animal per day }\end{array}$} \\
\hline & Treatment & Control & Treatment & Control & Treatment & Control \\
\hline \multicolumn{7}{|l|}{ 1. Saaradabatase } \\
\hline Feed compounded & 59.18 & 60.0 & 140.30 & 119.42 & - & - \\
\hline UMMB & 6.75 & - & - & - & - & - \\
\hline Rice bran & 44.18 & 40.0 & & & & \\
\hline Total & 110.11 & 100.0 & 140.30 & 119.42 & 30.19 & 19.42 \\
\hline \multicolumn{7}{|l|}{ 2. Nala } \\
\hline Feed compounded & $55.0^{*}$ & 55.0 & 136.1 & 115.84 & - & - \\
\hline UMMB & 6.75 & - & & & & \\
\hline Rice bran & 44.18 & 40.0 & - & - & - & - \\
\hline Total & 105.92 & 95.0 & 136.30 & 119.42 & 30.38 & 24.42 \\
\hline \multirow{2}{*}{\multicolumn{4}{|c|}{ Additional net return with UMMB supplementation NRs/animal/day }} & \multirow{2}{*}{\multicolumn{2}{|c|}{$\begin{array}{l}\text { Saaradabatase } \\
\text { Nala }\end{array}$}} & 10.77 \\
\hline & & & & & & 5.96 \\
\hline
\end{tabular}

Note: * cost of green grass has not been included 


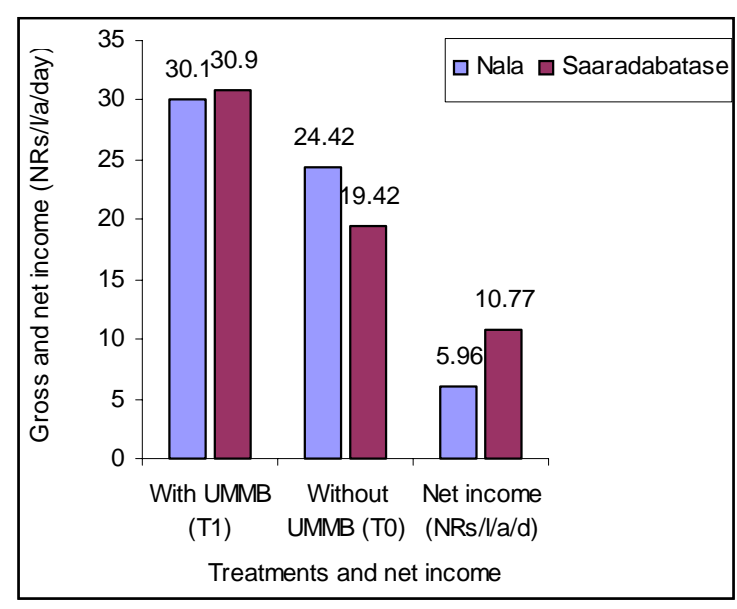

Fig 3. Economic return of UMMB supplementation

\section{Acknowledgements}

We are thankful to the farmers who provided the animals, feeds and labor to conduct the study. Thanks go to the Dairy Co-operative for helping fat and SNF analysis. We are grateful to Ms Debi Kumari Dhakal for her generous support to conduct the training and research in the field. SM Pradhan is acknowledged for commenting on this manuscript.

\section{References}

Anonymous. 2009. Urea molasses minaral block (UMMB) in lactating dairy animals. In: Annual report, 2008/ 2009.Animal Nutrition Division, NASRI, Khumaltar, Lalitpur. Nepal. 11 pp.
Anonymous. 2010. Intigrated approach for improving dairy animal production for sustainable livelyhood improvement. In: Annual repoprt. 2009/2010. Bovine Research Program, NASRI Khumaltaer, Lalitpur, Nepal pp. 10.

Aarts, G., R. Sansoucy and G.P. Levieux.1990. Guideline for the manufacture and utilization of molasses - urea blocks. Animal Production and Health Division, FAO, Rome, Italy. 7pp.

AOAC. 1999.Official methods of analysis. Association of Official Analysis Chemists, Washington, D.,C.

Avilla, H. F. 2006. Production and utilization of urea molasses mineral block (UMMB). FAO/ Ag./AGP/ doc/publicat/VIET95, Pp. 199-204.

Bheekhee, H. 2010. Urea molasses multinutrient blocks (UMMB) as a feed supplement for ruminants. www.gov.mu/portal/sites/ncb/moa//farc/amas99/ p2.htm . Pp. 1-3.

Khan, M.A.S and M.A.R. Chowdhury. 2000. Urea molasesses blocks to improve milk production and reproductive performance of crossbred dairy cattle under smallholder farm condition in Bangaladesh. www.fao.org/teca/system/files/45_056.pdf Pp. 123-124.

Makkar, H. 2001. Frequently asked questions on urea molasses-multinutrient block technology (UMMB). Report on review meeting - International Atomic Energy Agency (IAEA) Vienna, Ausria. Pp. 1-16.

Mandal, P., B. S. Kunwar, H. R. Shrestha and M. S. Thapa. 2001. Technology from bovine research program. Bovine Research Program, Khumaltar, Lalitpur, Nepal. Pp. 41- 46.

Pande, R. S. 1997. Fodder and pasture development in Nepal. Udaya Research and Development Service (P) Ltd. publisher, Kathmandu, 5 pp.

Upreti, C. R. 2008. Buffalo. In: Livestock poultry and fish nutrition in Nepal. B. Upreti publisher, Kathmandu. Pp. 117-120. 
Nepal Journal of Science and Technology 11 (2010) 71-78 